\title{
PODER DE POLÍCIA AMBIENTAL
}

\author{
Power of Environmental Police
}

\section{Cíntia Schmidt}

Advogada. Especialista em Direito Ambiental Nacional e Internacional pela UFRGS. Mestra em Fundamentos Constitucionais da PUCRS. Professora universitária do Centro Universitário Metodista IPA. Membro integrante da Comissão de Direito Ambiental da OAB/RS.

\section{Resumo}

O tema escolhido no presente artigo, o poder de polícia ambiental, envolve dois ramos do Direito de fundamental importância: o Direito Ambiental e o Direito Administrativo, os quais se interpenetram, formando um novo "Direito Administrativo Ambiental", devendo ser feita uma nova leitura. Note-se que o poder de polícia ambiental é um instrumento fundamental para a consecução desse Direito Administrativo Ambiental, tendo em conta o direito fundamental à boa Administração Pública e ao meio ambiente ecologicamente equilibrado. Nesse sentido, é um direito que está ainda em construção, incorporando ainda o princípio do desenvolvimento sustentável, dentre os objetivos fundamentais da República Federativa do Brasil.

Palavras-chave: Poder de Polícia Ambiental. Novo Direito Administrativo Ambiental.

\section{Abstract}

The theme chosen in this article, the power of environmental police, involves two branches of Law of fundamental importance: Environmental Law and Administrative Law, which interpenetrate, forming a new "Environmental Administrative Law" and a new reading. It should be noted that environmental police power is a fundamental instrument for the achievement of this Environmental Administrative Law, taking into account the fundamental right to good Public Administration and the ecologically balanced environment. In this sense, it is a right that is still under construction, still incorporating the principle of sustainable development, among the fundamental objectives of the Federative Republic of Brazil.

Keywords: Power of Environmental Police. New Environmental Administrative Law.

\section{Sumário}

1. Introdução; 2. Conceito de poder de polícia ambiental; 3. Finalidade e fundamentos do poder de polícia; 4. Atributos; 5. Fundamento do poder de polícia ambiental; 6. Competência para o exercício e sanções aplicáveis; 7 . Conclusões; 8. Notas; Referências. 


\section{INTRODUÇÃO}

Pretende-se demonstrar que o Direito Administrativo não pode mais ser concebido sem incorporar a variável ambiental. Nesse sentido, não há qualquer possibilidade da Administração Pública atuar sem observar as condicionantes ambientais, devendo, inclusive, adotar critérios sustentáveis nas compras públicas, de acordo com a nova redação do art. $3^{\circ}$, da Lei n. 8.666, alterado pela Lei n.12.349/2010, que trouxe na sua redação a observância do desenvolvimento nacional sustentável.

Importante ressaltar que as políticas públicas devem ser realizadas, visando ao direito fundamental à boa administração pública ${ }^{1}$ e ao meio ambiente ecologicamente equilibrado $^{2}$, além do princípio constitucional do desenvolvimento sustentável, portanto, devem ser eficientes, uma vez que há dever do Poder Público de empregar todos os meios disponíveis para que se obtenha os melhores resultados na consecução dos direitos fundamentais (SCHMIDT, 2011).

Destaque-se que o poder de polícia ambiental, deve ser visto como um instrumento que visa a dar maior efetividade à normativa ambiental, tendo em vista que se apresenta um "Novo Direito Administrativo Ambiental" com uma nova postura de atuação do Poder Público, correspondendo a um instrumental da esfera administrativa que se coaduna com os anseios democráticos e com a ideia de boa governança, exigindo da Administração Pública vinculação aos mandamentos constitucionais, devendo a sua atuação se dar de forma preventiva e responsiva, imbuídos de um agir de forma ética por parte dos seus agentes públicos.

\section{DIREITO FUNDAMENTAL À BOA ADMINISTRAÇÃO PÚBLICA}

Hodiernamente, visualiza-se o direito não apenas como um conjunto de regras, mas também, como um conjunto de princípios e regras (FREITAS, 2010, p.229), assumindo relevo outros princípios além (e não de maneira a excluí-lo) do princípio da legalidade, como o princípio da eficiência, da proporcionalidade, dentre tantos outros, indispensáveis à tutela do direito fundamental à boa Administração Pública, somando-se ainda a variável ambiental, do direito fundamental ao meio ambiente ecologicamente equilibrado e do desenvolvimento sustentável, previstos nos artigos 225 e 170, VI, ambos da Constituição Federal, além do objetivo fundamental da República Federativa do Brasil de garantir o desenvolvimento nacional, o qual não pode ser outro senão o desenvolvimento sustentável.

A passagem da Constituição para o centro do ordenamento jurídico resultou na mudança de paradigmas em todos os ramos do Direito, especialmente do Direito Administrativo. É exatamente a supremacia da Constituição que propicia a impregnação de toda atividade da Administração Pública pelos princípios, regras e valores nela previstos, ensejando uma releitura da disciplina pela ótica constitucional, em uma perspectiva hermenêutica (BINENBOJN, 2006).

Inspirado no art. 41, da Carta dos Direitos Fundamentais da União Europeia ${ }^{3}$ (Carta de Nice, 2000), o direito fundamental à boa administração deve ser compreendido como o 
direito à "Administração Pública eficiente e eficaz, proporcional cumpridora de seus deveres, com transparência, motivação, imparcialidade e respeito à moralidade, à participação social e à plena responsabilidade por suas condutas comissivas e omissivas" (FREITAS, 2009).

O direito à boa administração, no Brasil, encontra amparo nos artigos 37, caput e artigo 70, caput. Nesse sentido, no Estado Democrático de Direito, a Administração Pública apresenta uma nova realidade, dando asas à nova interpretação sistemática do Direito Constitucional Administrativo (FREITAS, 2010). Nesse diapasão, vislumbra-se uma releitura do Direito Administrativo, notadamente com o avanço do Direito Ambiental, formando o "Novo Direito Administrativo Ambiental". Não se pode negar a influência do Direito Ambiental no novo Direito Administrativo, defendendo-se uma interação absoluta entre as duas áreas conexas.

A propósito, cogita-se desse "Novo Direito Administrativo":

\begin{abstract}
O Direito Administrativo, no século XXI, vencido o paradigma da razão monológica, haverá de ser o direito da discricionariedade administrativa legítima, isto é, das escolhas justificáveis. Será, pois, o direito da motivação consistente. Convergirá, nessa linha, com o inspirador art. 41 da Carta dos direitos fundamentais de Nice, guiada por direitos e princípios, acima de paixões e de imediatismos ensejadores de onerosos conflitos. Assim, para além do utilitarismo, não será o Direito Administrativo dos aparatos secundários ou das maiorias ocasionais, mas do interesse de todos e dos princípios fundamentais devidamente entrelaçados e hierarquizados, numa aplicação tópico-sistemática congruente (FREITAS, 2008, p. 311).
\end{abstract}

Destaque-se que o poder de polícia ambiental é um instrumento que preconiza dar maior efetividade à normativa ambiental, tendo em vista que se apresenta um "Novo Direito Administrativo Ambiental" com uma nova postura de atuação do Poder Público, com um agir preventivo e responsivo, por parte dos seus agentes públicos. Almeja-se demonstrar que a realização deste está intimamente relacionada com a incorporação da variável ambiental, que deve permear todas as relações administrativas, em uma visão sistêmica e com um planejamento de longo prazo, tendo em vista o paradigma que se apresenta de uma nova postura da Administração Pública. E, com essa nova postura, o setor empresarial também deverá se adequar, procurando agir de forma preventiva, antes mesmo que qualquer infração ambiental possa ocorrer e a Administração Pública tenha que atuar.

No momento em que se aborda o regime jurídico-administrativo a que fica submetido à Administração Pública, conclui-se que os dois aspectos fundamentais que o caracterizam se resumem nos vocábulos prerrogativas e sujeições: as primeiras, concedidas à Administração, para oferecer-lhes os meios para assegurar o exercício de suas atividades, e as segundas, como limites opostos à atuação administrativa em benefício dos direitos dos cidadãos. Praticamente, todo o Direito Administrativo cuida de temas em que se colocam em tensão dois aspectos opostos: a autoridade da Administração Pública e a liberdade individual. Complementa ainda a autora que o tema, relativo ao poder de polícia, é um daqueles em que se colocam em confronto esses dois aspectos. De um lado, o cidadão quer exercer plenamente os seus direitos; de outro, a Administração tem por incumbência condicionar o exercício daqueles direitos ao bem-estar coletivo, e ela o faz, usando de seu poder de polícia (DI PIETRO, 2008, p.105). 
Também, é fundamental registrar que a polícia administrativa é exercida sobre atividades privadas, bens ou direitos, enquanto a polícia judiciária incide diretamente sobre as pessoas. A polícia administrativa é desempenhada por órgãos administrativos de caráter fiscalizador, integrantes dos mais diversos setores de toda a Administração Pública, como por exemplo, o IBAMA- Instituo Brasileiro do Meio Ambiente e dos Recursos Naturais Renováveis, ao passo que a polícia judiciária é executada por corporações específicas, no caso, as polícias civis ou militares. Ainda, a polícia administrativa se vale de regras administrativas e as sanções aplicadas são típicas de Direito Administrativo, ao passo que a polícia judiciária se vale dos tipos penais para agir sobre a pessoa. No artigo presente, trataremos apenas da polícia administrativa.

\section{CONCEITO DE PODER DE POLÍCIA AMBIENTAL}

A expressão "poder de polícia", em sentido amplo, remontando aos anos sessenta, como "exercício do poder sobre as pessoas e as coisas, para atender ao interesse público, e o define como a disciplina das atividades individuais, imposta pela coletividade, cujos direitos devem ser respeitados pelos indivíduos" (CAVALCANTI, 1964, p.05).

Já para Diogo de Figueiredo Moreira Neto, o "poder de polícia é a atividade administrativa que tem por objeto limitar e condicionar o exercício de direitos fundamentais, compatibilizando-os com interesses públicos legalmente definidos, com o fim de permitir uma convivência ordeira e valiosa" (MOREIRA NETO, 2005, p. 395).

De acordo com MELLO, a expressão poder de polícia é criticada, pois engloba, sob um único nome, coisas radicalmente distintas, submetidas a regime de inconciliável diversidade: leis e atos administrativos, isto é, disposições superiores e providências subalternas. Isto já seria fonte das mais lamentáveis e temíveis confusões, pois leva, algumas vezes, a reconhecer à Administração poderes que seriam inconcebíveis no Estado de Direito, dando-lhe uma sobranceira que não possui, por ser imprópria de quem nada mais pode fazer senão atuar com base em lei que lhe confira os poderes tais ou quais a serem exercidos nos termos e forma por ela estabelecidos. Aduz que a expressão "poder de polícia" traz consigo a evocação de uma época pretérita, a do "Estado de Polícia", que precedeu ao Estado de Direito. Traz consigo a suposição de prerrogativas antes existentes em prol do "príncipe" e que se faz comunicar inadvertidamente ao Poder Executivo. Por fim, embora pareça uma terminologia indesejável, ela persiste largamente utilizada entre nós, não podendo desconhecê-la, daí porque continuará a se servir dela, tratando o tema sob essa mesma rubrica (MELLO, 2008, p.808).

Optou-se por adotar o termo "poder de polícia", tendo em vista que a expressão permanece sendo utilizada em nosso sistema jurídico, mas fica a ressalva quanto ao seu uso que remonta os ecos do sombrio e famigerado "Estado de Polícia" (FREITAS, 2009, p.187). O referido autor propõe uma revisão categorial, levando em consideração as transformações paradigmáticas do Direito Administrativo, patrocinada pela primazia dos direitos fundamentais, em especial do direito fundamental à boa Administração Pública. Assim, deve haver vinculação do primado simultâneo dos objetivos, previsto na Constituição Federal, no seu art. $3^{\circ}$ e dos direitos fundamentais (FREITAS, 2009, p.207), conceituando o poder de polícia 
administrativa da seguinte forma:

Exercício de um dever (não mera faculdade) que consiste em regular, restringir ou limitar administrativamente, de modo legal e legítimo, o exercício dos direitos fundamentais de propriedade e liberdade, de maneira a obter, mais positiva do que negativamente, uma ordem pública capaz de viabilizar a coexistência dos direitos em sua totalidade, sem render ensejo à indenização, por não impor dano juridicamente injusto.

Tem-se como definição sobre poder de polícia: "poder de polícia administrativa é a competência para disciplinar o exercício da autonomia privada para a realização de direitos fundamentais e da democracia, segundo os princípios da legalidade e da proporcionalidade" (JUSTEN FILHO,2014, p. 585).

O conceito legal sobre poder de polícia está previsto no artigo 78 do Código Tributário Nacional "como atividade da Administração Pública que, limitando ou disciplinando direito, interesse ou liberdade, regula a prática de ato ou abstenção de fato, em razão do interesse público concernente aos direitos individuais e coletivos". O STF ${ }^{4}$ absorveu esse conceito.

A expressão "poder de polícia" conceituada "como a atribuição conferida à Administração Pública para condicionar e restringir o uso e o gozo de bens e o exercício de atividades e direitos individuais, com o objetivo de compatibilizá-los com o interesse público ou social" (FINK; ALONSO JÚNIOR; DAWALIBI, 2004, p.93).

No tocante ao poder de polícia ambiental (MACHADO, 2010, p. 341) o conceitua como correspondente:

\footnotetext{
à atividade da administração pública que limita ou disciplina direito, interesse ou liberdade, regula a prática de ato ou a abstenção de fato, em razão de interesse público concernente à saúde da população, à conservação dos ecossistemas, à disciplina da produção e do mercado, ao exercício de atividades de concessão, autorização, permissão ou licença do poder público de cujas atividades possam decorrer poluição ou agressão à natureza.
}

Sugere-se definir o poder de polícia ambiental da seguinte forma: poder-dever da Administração Pública de defender o meio ambiente ecologicamente equilibrado, mediante intervenção proporcional, sem omissão relevante, na esfera jurídica dos administrados seja pessoa física ou jurídica- com vistas a evitar ou reprimir o exercício insustentável dos direitos de propriedade e de liberdade (SCHMIDT, 2012, p.57).

Desta feita, a doutrina converge no sentido de limitação ou restrição por parte do Estado às liberdades e às propriedades individuais em prol do bem comum, do interesse público. A partir dessa premissa, tem-se que a proteção dos direitos fundamentais à boa administração pública e ao meio ambiente ecologicamente equilibrado, bem como a aplicação do princípio constitucional do desenvolvimento sustentável é dever-poder do Estado, por meio do poder de polícia ambiental.

\section{FINALIDADE E FUNDAMENTOS DO PODER DE POLÍCIA}

O poder de polícia encontra respaldo na prerrogativa que tem a Administração Pública de zelar pela ordem pública. Importante ressaltar que a omissão do Poder Público no seu

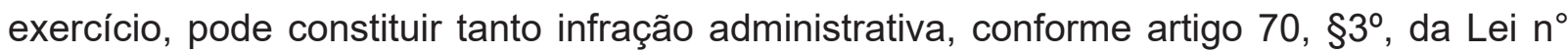
9.605/98 (Lei de Crimes Ambientais), quanto ato de improbidade administrativa, com previ- 
são no artigo 11, incisos I e II, da Lei n 8.429/92.

É relevante destacar que o poder de polícia deve ter condições de regularidade para que ele seja válido. Nesse sentido, (MUKAI, 2006) aponta as seguintes condições:
a) atuação do órgão nos limites de sua competência;
b) atuação nos limites de lei formal que seja, de acordo com a Constituição, de competência da entidade política federativa;
c) com observância do devido processo legal, ou seja, assegurado o contraditó- rio e a ampla defesa, nos termos do art. $5^{\circ}$, LV, da Constituição;
d) o poder de polícia pode se manifestar através de atos vinculados ou discricio- nários, nesta última hipótese, dentro do âmbito de liberdade que a lei conceder ao administrador; porém mesmo aqui, o exercício há de ser regular, ou seja, sem abuso ou desvio de poder.

Defende-se que não existe mais a discricionariedade ${ }^{5}$ pura, de sorte que todos os atos administrativos, para possuírem validade e legitimidade, devem estar revestidos dos princípios cimeiros (FREITAS, 2010) que regem as relações da Administração Pública, havendo uma progressiva revisão de categorias clássicas.

A prática do poder vincula e responsabiliza, tendo em vista que os direitos fundamentais não se afiguram singelas ou estritas expressões de contrapartida dos direitos atribuídos ao Poder Público: configuram autênticos direitos legitimadores, por assim dizer do Estado. Logo, nas relações de Direito Administrativo, os direitos fundamentais devem ser precipuamente promovidos e preservados com seriedade. Quer dizer, sacrifícios razoáveis, por boas razões, mostram-se até admissíveis, contanto que não resultem do arbítrio (por ação ou omissão), supostamente "legalizado" pela ordem vigente. Desse modo, afetados os direitos fundamentais, por atos comissivos ou omissivos, cogente a pronta compensação e a imediata cessação da prática nociva ou ameaçadora (FREITAS, 2010).

O poder de polícia ambiental é passível de invocação através de ordens e proibições, mas, sobretudo, por meio de normas limitadoras, dentro da licitude do ordenamento jurídico pátrio, obedecendo ao preconizado pelo artigo 225 da Constituição Federal. Salienta-se que um dos meios de atuação do poder de polícia corresponde à fiscalização, a qual visa à adequação do comportamento individual à lei. Essa fiscalização deve ser preventiva, preferencialmente, devendo-se aparelhar a polícia administrativa para que possa cumprir seu papel efetivamente.

Por certo que há restrições no exercício dos direitos à propriedade e à liberdade. No entanto, não enseja reparação indenizatória, quando o ato de polícia estiver revestido de legalidade, além da proporcionalidade. Como relembra (FREITAS, 2010) não é suficiente o respeito isolado à legalidade formal, se a desproporcionalidade estiver consubstanciada, dando o exemplo de uma multa, baseada em lei inconstitucional, o que não pode prosperar.

A razão do poder de polícia é a supremacia do interesse público, e o seu fundamento está na supremacia geral que o Estado exerce em seu território sobre todas as pessoas, bens e atividades, supremacia que se revela nos mandamentos constitucionais e nas normas de ordem pública que, a cada passo, opõem condicionamentos e restrições aos direitos individuais em favor da coletividade, incumbindo ao Poder Público o seu policiamento administrativo (MEIRELLES, 2000, p. 116). Ocorre que o interesse social legítimo sempre 
prevalece em detrimento do interesse do particular, ainda mais quando está se falando de ações que não se encaixam dentro da licitude no ordenamento jurídico vigente pátrio.

Lembra-se que o artigo $3^{\circ}$ da Constituição Federal, no seu inc. IV prevê, dentre os objetivos fundamentais da República Federativa do Brasil, "promover o bem de todos", que, traduzindo, demonstra buscar o interesse público, além do inciso II, "garantir o desenvolvimento nacional”, que não poder ser outro que não o desenvolvimento sustentável.

Em respeito ao requisito da finalidade do ato administrativo, a Administração deve, previamente, declinar o mote de sua ação fiscalizatória. O poder de polícia: não deve ir além do necessário para a satisfação do interesse público que visa a proteger; a sua finalidade não é destruir os direitos individuais, mas, ao contrário, assegurar o seu exercício, condicionando-o ao bem-estar social; só poderá reduzi-los, quando, em conflito com interesses maiores da coletividade, e na medida estritamente necessária à consecução dos fins estatais (DI PIETRO, 2007, p.109).

Segundo DAWALIBI, os direitos individuais não são absolutos, de modo que não pode alguém, a pretexto de exercer um direito subjetivo, fazê-lo de forma a prejudicar valores de interesse de toda sociedade. Tal mensagem está clara na própria Lex Legum, que, ao mesmo tempo em que, no seu artigo $5^{\circ}$, garante direitos e liberdades individuais fundamentais, faz ressalvas e restrições para a garantia do interesse social. Assim o faz, v.g., na medida em que garante o direito à propriedade (inc. XXII), mas o condiciona ao cumprimento de sua função social (inc. XXIII). ${ }^{6}$ Lembrando-se ainda, que o Código Civil, no seu artigo 1.228, $\S 1^{\circ}$, trouxe uma grande inovação ao condicionar o exercício do direito de propriedade à função socioambiental ${ }^{7}$ da propriedade.

Para (MEDAUAR, 2007, p. 336) o poder de polícia "visa a propiciar a convivência social mais harmoniosa possível, para evitar ou atenuar conflitos no exercício dos direitos e atividades dos indivíduos entre si e ante o interesse de toda população".

O poder de polícia é inerente à atividade da Administração Pública, devendo ser exercido sobre todas as condutas ou quaisquer situações que possam afetar os interesses da coletividade, de forma direta ou indireta. Impende ressaltar que a Administração Pública, quando atua no exercício do poder de polícia, limitando os exercícios de liberdade e de propriedade, deve estar revestida com base no que está disposto em lei, uma vez que o princípio da legalidade norteia e baseia toda a atividade da Administração Pública. Lembra-se aqui que limitar não corresponde a impedir o seu exercício, mas a limitação pode ser exercida, objetivando o bem-estar coletivo.

Desta feita, o poder de polícia busca harmonizar o convívio social, através da supremacia que se revela nos mandamentos constitucionais, dos direitos fundamentais e nas normas de ordem pública ditadas pela Administração Pública.

\section{ATRIBUTOS}

O poder de polícia possui como atributos a autoexecutoriedade e a coercibilidade, dotada esta de proporcionalidade, além da indenização zero. 
A autoexecutoriedade significa que o agente público do Poder Executivo deve agir, sem ter de pedir autorização aos Poderes Judiciário e Legislativo. De acordo com (Freitas, 2009, p.202) a autoexecutoriedade é traço apenas contingente do exercício regular do poder de polícia administrativa. Refere que o exercício lícito da polícia administrativa pode acontecer, desde que a urgência o requeira, por meio de medidas autoexecutórias que dispensam prévia autorização judicial, desde que prontamente disponíveis os remédios para conter os eventuais abusos. Constatados o desvio da finalidade ou o prejuízo desproporcional (dano anômalo e não eventual), cabe a responsabilização objetiva do Estado por atos dos seus agentes, nessa qualidade, sem excluir o abrangente arco das sanções adicionais.

Na esteira da lição de (MELLO, 2008, p. 828):

As medidas de polícia administrativa frequentemente são autoexecutórias: isto é, pode a Administração Pública promover, por si mesma, independentemente de remeter-se ao Poder Judiciário, a conformação do comportamento do particular às injunções dela emanadas, sem necessidade de um prévio juízo de cognição e ulterior juízo de execução processado perante as autoridades judiciárias.

Nesse passo, dado que "a lei não excluirá da apreciação do Poder Judiciário a lesão ou ameaça ao direito" (inc. XXXV, do artigo $5^{\circ}$, da Constituição Federal), ainda que em sede de controle a posteriori, os atos administrativos, mesmo os autoexecutáveis, devem ser pautados pelos requisitos da competência, proporcionalidade e da motivação. Isso redunda em que o Agente deva possuir autorização legal para agir. Assim, decorre que o exercício do poder de polícia é efetivado pelo conjunto de atos administrativos revestidos de cuidados com a legalidade e demais princípios que compõem o Direito Administrativo.

A autoexecutoriedade é a faculdade que a Administração Pública tem de executar diretamente a sua decisão por seus próprios meios, sem a intervenção do Judiciário. Através do uso desse poder, a Administração impõe diretamente as medidas ou as sanções de polícia administrativa, necessárias à contenção da atividade antissocial que ela visa a obstar (FREITAS, 2009, p.120).

Desse modo, a demolição de uma obra que ameaça ruir e a interdição de estabelecimento que encerra atividade poluente, a exemplo de outras medidas, é efetivada do mesmo modo, isto é, sem prévio aviso ou posterior pronunciamento do Poder Judiciário.

Já, a coercibilidade demonstra uma imposição por parte da Administração que poderá exigir condutas do administrado, o qual não poderá se abster de cumpri-las. Desse modo, caso o particular queira resistir, a Administração Pública pode se valer de todos meios necessários, inclusive força policial, para aplicar a sua determinação.

Há prerrogativa que a Administração pode (leia-se deve) exigir que o fiscalizado esteja adequado à normatização prevista na defesa do interesse público. Conforme defende (FREITAS, 2009, p.192), ainda que se trate de dever, situações há em que a Administração precisa exercer escolhas, ora no plano das consequências, ora quanto ao momento de agir. Ou seja: ao se reconhecer que se trata de dever, não se comete o erro de suprimir a relativa liberdade do agente público, em dados contextos, para escolher não agir ou adiar a ação, de modo motivado e autorizado por lei. O que se proíbe é tão-somente a inércia antijurídica. $\mathrm{E}$, complementa o autor, que seria o caso de imposição coativa, inclusive porque a disciplina, 
para o salutar funcionamento da vida em sociedade, deve ser obtida, preferencialmente até pela via da persuasão ou conciliação, reservando-se a execução administrativa forçada para aquelas situações de inexistência de outra solução e, não raro, para proteger a dignidade ou a vida daqueles que resistem à limitação. Também traz à baila, detalhe deveras significativo: os casos em que a pessoa jurídica de direito privado, integrante da Administração Pública pode sofrer restrição administrativa, como exemplo frequente uma sociedade de economia mista, multada por agência reguladora, em função de reiteradas atividades poluidoras, tendo em vista o regime estatuído no artigo 173, da Constituição Federal.

No caso do poder de polícia ambiental, é obrigatória a sua fiscalização de atividades potencialmente poluidoras, impondo-se até mesmo em relação à poluição causada pela própria Administração Pública, podendo, inclusive, a pessoa jurídica de direito público ser responsabilizada, como defende Freitas, posição com a qual há absoluta concordância dessa autora.

Outro atributo, menos abordado, mas não menos importante que os demais, corresponde à indenização zero, ou seja, sem direito à indenização. Assevera que a prática legal e legitimadas limitações administrativas impõem sacrifícios socialmente aceitáveis, isto é, não pode afetar o cerne dos direitos fundamentais de propriedade e de liberdade, motivo pelo qual não se apresenta ensejadora de indenização, uma vez que se cinge a obstar que determinado dano à coletividade ocorra ou prossiga, longe de impor prejuízos iníquos aos particulares. E complementa que se diferencia, por exemplo, da desapropriação, pois esta implica sacrifício total de direitos patrimoniais, sendo forma de aquisição originária da propriedade, enquanto aquela é tão-só uma limitação ao exercício dos direitos - especialmente os de liberdade e de propriedade - normalmente impondo uma abstenção, nunca um despojamento. Igualmente, distingue-se da servidão administrativa porque não impõe à propriedade particular ônus real de uso, tampouco se sujeita à indenização, uma vez que não gera prejuízos suportados pelo proprietário, assim como sucede corriqueiramente nas servidões públicas (FREITAS, 2009, p. 204).

Na realidade, quando se trata de indenização zero, em relação ao poder de polícia, demonstra-se que houve a prática legal e legítima do Poder Público, atendendo a todos os princípios integrantes da Administração Pública.

Além de seus atributos, as medidas de polícia, para ostentarem condições de validade, devem estar revestidas pela competência, finalidade e forma, além de serem acrescidas da proporcionalidade e da legalidade dos meio empregados pela Administração.

\section{FUNDAMENTO DO PODER DE POLÍCIA AMBIENTAL}

Tratando-se de poder de polícia, verifica-se, como fundamento, a supremacia do interesse social sobre o individual e, da mesma forma, ocorre com o poder de polícia em matéria ambiental, já que o meio ambiente ecologicamente equilibrado ocupa posição de relevo na Constituição Federal, sendo um direito fundamental, previsto no seu artigo 225.

Já o artigo 145, inciso II, da Constituição Federal prevê a cobrança de taxas, tendo em vista o poder de polícia. Impende destacar que as taxas, decorrentes do poder de polícia 
ambiental, deveriam ser utilizadas para a finalidade precípua de aparelhar os órgãos estatais responsáveis pela fiscalização ambiental e, até mesmo, realizar novas contratações de funcionários para que possam dar maior efetividade no desempenho de suas funções, o que muitas vezes não ocorre.

Assim, quando a Constituição determina que o Poder Público, bem como a coletividade, têm o dever de defender o meio ambiente, demonstra-se que o exercício do poder de polícia é obrigatório por parte do Estado, visto que é assegurador do primado dos princípios, objetivos, direitos e deveres fundamentais ${ }^{8}$. Ainda, o $\S 1^{\circ}$ do referido artigo institui alguns atos de polícia para a defesa do meio ambiente, tais como a fiscalização de entidades destinadas à pesquisa e manipulação de material genético (inc. II), o zoneamento ambiental (inc. III), além do importante Estudo de Impacto Ambiental (inc. IV). Também, no $§ 2^{\circ}$, a exigência de Plano de Recuperação de Área Degradada em atividades mineradoras; no $\S 3^{\circ}$ as sanções administrativas contra atividades causadoras de danos ambientais, definidas em lei; no $\S 4^{\circ}$, define-se que a Floresta Amazônica brasileira, a Mata Atlântica, a Serra do Mar, o Pantanal Mato-Grossense e a Zona Costeira são patrimônio nacional, e sua utilização far-se-á na forma da lei, dentro de condições que assegurem a preservação ambiental, inclusive quanto ao uso dos recursos naturais.

Ainda que o artigo 225 da Magna Carta seja o pilar de sustentação do poder de polícia ambiental e haja a previsão no artigo 145, inciso II, o qual prevê a cobrança de taxas, tendo em vista o poder de polícia, encontram-se vários artigos que obrigam o Poder Público a defender o meio ambiente, como no caso do artigo 23, no seu inc. VI, que dispõe ser competência comum da União, Estados, Distrito Federal e dos Municípios proteger o meio ambiente e combater a poluição em qualquer de suas formas (inc. VI) e preservar as florestas, a fauna e a flora (inc. VII). O artigo 24 dispõe que compete à União, aos Estados e ao Distrito Federal legislar concorrentemente sobre 'florestas, caça, pesca, fauna, conservação da natureza, defesa do solo e dos recursos naturais, proteção do meio ambiente e controle da poluição (inc. VI) e também sobre a responsabilidade por dano ao meio ambiente (inc. VIII).

Efetivamente, há uma nova visão sistêmica ${ }^{9}$ e de longo prazo com a incorporação da variável ambiental, procurando promover o desenvolvimento sustentável, única forma de desenvolvimento possível nos dias hodiernos.

\section{COMPETÊNCIA PARA O EXERCÍCIO E SANÇÕES APLICÁVEIS}

De modo geral, a competência para exercer o poder de polícia segue a competência legislativa, através da qual o ente que a Lei Maior outorgou à competência legislativa sobre determinada matéria, também terá a competência para exercer a polícia administrativa sobre ela.

No que tange à competência material comum, verifica-se que o legislador constituinte delimitou uma área de competência que deve ser exercida conjuntamente entre os entes federados, isto é, a União, Estados, Distrito Federal e Municípios, que deverão partilhar a responsabilidade pela gestão ambiental. A competência comum é aquela em que, relativa- 
mente a uma determinada matéria, concorre mais de um ente político, estando prevista no art. 23, inc. VI da Constituição Federal.

Decorre desse dispositivo, a manifesta vontade do legislador no sentido de que os poderes públicos, indistintamente, cooperem na execução das tarefas ambientais, incluindo aqui o exercício do poder de polícia. Isto é, a responsabilidade de zelar pelo meio ambiente não pode ficar submetida a questões relacionadas com limites jurisdicionais ou espaços territoriais de cada ente político. São todos, neste caso, compelidos a cumprir e fazer cumprir tais obrigações, pois possuem o dever fundamental.

Para (SILVA, 2003, p. 77) o artigo 23 da Constituição dispõe sobre a competência comum da União, dos Estados, do Distrito Federal e dos Municípios. Essa competência diz respeito à prestação dos serviços referentes àquelas matérias, à tomada de providências para a sua realização. A propósito, a Lei Complementar $n^{\circ}$ 140, de 08 de dezembro de 2011, fixa normas, nos termos dos incisos III, VI e VII do caput e do parágrafo único do art. 23 da Constituição Federal, para a cooperação entre a União, os Estados, o Distrito Federal e os Municípios nas ações administrativas decorrentes do exercício da competência comum relativas à proteção das paisagens naturais notáveis, à proteção do meio ambiente, ao combate à poluição em qualquer de suas formas e à preservação das florestas, da fauna e da flora; e altera a Lei $n^{\circ} 6.938$, de 31 de agosto de 1981. No entanto, pouco se viu até o presente momento em relação à cooperação entre os entes federados.

Alguns incisos do artigo se referem à proteção do meio ambiente cultural ou natural. Assim é que se atribui àquelas entidades, cumulativamente, a competência para proteger as obras e outros bens de valor histórico, artístico e cultural, os monumentos, as paisagens naturais notáveis e os sítios arqueológicos (inciso III), bem como a competência para impedir a distribuição e a descaracterização de obras de arte e de outros bens de valor histórico, artístico ou cultural (inciso IV). Já no tocante ao meio ambiente natural, encontra-se a competência comum para protegê-lo e para combater a poluição em qualquer de suas formas (inciso VI), assim como para preservar as florestas, a fauna e a flora (inciso VII).

Interessante notar a reflexão acerca dos direitos fundamentais e a atuação conjunta do Poder Público e dos cidadãos. Tendo em conta que a mera limitação do Estado se mostrou incapaz para uma garantia total da liberdade, isto é, para a consecução efetiva da liberdade, fez-se necessária uma ampliação do âmbito de abrangência dos direitos fundamentais. Este alargamento do conteúdo implica que se depreenda dos direitos fundamentais não apenas uma defesa contra a limitação do exercício da liberdade individual pelo Estado, mas também, mecanismos para a promoção da liberdade. Fundamental o destaque que a autora atribui para os direitos fundamentais, eis que exerciam preponderantemente funções limitativas (o exercício da liberdade individual só é limitado pelo exercício da liberdade de outro). Hoje, o seu maior papel está em ações constitutivas, operadas tanto pelo Estado como pelos agentes privados. Esta compreensão inovadora dos direitos fundamentais está pautada em uma premissa essencial, a de que as liberdades individuais são indissociáveis das liberdades sociais ou coletivas. A realização do indivíduo não é passível de ser alçada sem a concreta difusão das liberdades pela sociedade como um todo. (DERANI, 2008, p.207) 
A questão está em saber, em cada caso concreto de competência comum, a que ente político está afeto o poder de polícia ambiental. Seguro, nesse passo, os ensinamentos de (SILVA, 1992, p. 198), no sentido de que a regra do artigo 23 da Constituição Federal deve ser interpretada da seguinte forma:

\footnotetext{
a) matérias de interesse local, isto é , que não extrapolem os limites físicos do Município, devem ser administradas pelo Executivo Municipal;

b) quando a matéria extrapola os limites físicos do Município, ou seja, os seus efeitos não ficam confinados na área física do município ou envolvam mais de um Município, desloca-se a competência do Executivo Municipal para o Executivo Estadual;

c) tratando-se de bens públicos estaduais e de questões ambientais supramunicipais, a competência será do Executivo Estadual;

d) nas hipóteses em que as matérias envolvam problemas internacionais de poluição transfronteiriça ou duas ou mais unidades federais brasileiras, a competência será do Executivo Federal.
}

Em relação à competência concorrente, está prevista no artigo 24 da Constituição Federal, na qual se declara competir à União, aos Estados e ao Distrito Federal legislar sobre florestas, caça, pesca, fauna, conservação da Natureza; a defesa do solo e dos recursos naturais; a proteção do meio ambiente e o controle da poluição (inciso VI); sobre a proteção ao patrimônio histórico, cultural, artístico, turístico e paisagísticos (inciso VII); assim como sobre a responsabilidade por dano ao meio ambiente, a bens e direitos de valor artístico, estético, histórico, turístico e paisagístico (inciso VIII).

Para MACHADO, 2010, p.117, há uma nova concepção de federalismo, uma vez que o meio ambiente está previsto como sendo de competência da União, dos Estados e do Distrito Federal, de forma concorrente (artigo 24). A concorrência enseja a possibilidade de iniciativa na área de legislação ambiental para os Estados e para o Distrito Federal, se a União se mantiver inerte. A competência concorrente poderá exercer-se não só quanto à elaboração de leis, mas, de decretos, resoluções e portarias.

Para atender às peculiaridades próprias, os Estados poderão exercer a competência legislativa plena, desde que não exista "lei federal sobre normas gerais" (artigo 24 , $\S 3^{\circ}$ ). Essa competência, chamada "plena", entretanto, sofre dupla limitação - qualitativa e temporal: a norma estadual não pode exorbitar da peculiaridade ou do interesse próprio do Estado e terá que se ajustar ao disposto em norma federal ambiental superveniente, observando-se a vedação da proibição de retrocesso.

Desta forma, a competência para a fiscalização e a aplicação de medidas de polícia segue a predominância do impacto, segundo a qual, compete à União as matérias em que predomine o impacto nacional; aos Estados, as de impacto regional; e aos Municípios, as de impacto local. Ressalta-se não haver prejuízo da competência supletiva - aquela que permite a atuação de determinado ente, quando ocorrer a omissão de outro precipuamente competente.

Há que se assinalar que, antes mesmo da Constituição Federal de 1988, a Lei Federal $n^{\circ}$ 6.938/81, mais conhecida como Política Nacional do Meio Ambiente, ao instituir o Sistema Nacional do Meio Ambiente, integrado pela União, Distrito Federal, Estados e Municípios, no seu artigo $6^{\circ}$, já dispunha nesse sentido. Então, a referida norma foi contemplada pela 
Lei Maior.

Desta feita, o poder de polícia, na esfera ambiental, é exercido pelos órgãos que integram o SISNAMA. O entendimento dos Tribunais Superiores acerca dos órgãos que detêm a competência está sedimentado. Portanto, tendo a Lei da Política Nacional do Meio Ambiente tratado sobre a competência do SISNAMA, sendo recepcionada a norma pela Constituição Federal, foi observada a regra, através da qual a competência legislativa sobre determinada matéria, também terá a competência para exercer a polícia administrativa sobre ela.

São diversas as sanções aplicáveis, previstas nas leis administrativas, em todos os níveis federativos, passíveis de serem aplicadas no âmbito do poder de polícia, incidindo sobre bens e atividades, não diretamente sobre os administrados, sejam pessoas físicas ou jurídicas, podendo inclusive sofrer o poder de polícia as pessoas jurídicas de direito público, não existindo sanções de polícia administrativa que impliquem detenção ou reclusão de pessoas. Podem ser citadas como sanções cabíveis: (a) multas administrativas; (b) interdição de estabelecimentos; (c) suspensão do exercício de direitos; (d) demolição de construções irregulares; (e) embargo administrativo de obra; etc.

A atuação do poder de polícia só será legítima se realizada de acordo com a legalidade, respeitados os direitos do administrado, além das prerrogativas individuais asseguradas pela Constituição Federal. Fundamental conciliar o interesse social com os direitos individuais consagrados no ordenamento jurídico pátrio. Caso a Administração Pública venha a agir além desses mandamentos, ferindo a intangibilidade do núcleo dos direitos individuais protegidos, configurando a sua atuação como arbitrária, estará caracterizado abuso de poder, perdendo a legitimidade de atuação do poder de polícia.

\section{CONCLUSÕES}

Diante de toda exposição no decorrer do presente artigo, no momento em que a Administração Pública veda ao particular um exercício de um direito para o qual não estava habilitado, é o caso típico do exercício do poder de polícia. Nessa senda, a propósito, o exercício do poder de polícia deve estar em consonância com o direito fundamental à boa administração pública e ao meio ambiente ecologicamente equilibrado, nessa visão sistemática do "novo Direito Administrativo Ambiental".

Ressalta-se que a Administração Pública deve preconizar restabelecer a ordem pública, dentro do poder (leia-se dever) conferido ao Estado, visando ao bem-estar da coletividade em detrimento de algum direito individual que estiver em dissonância com a ordem pública, atuando sempre de acordo com os princípios da legalidade e da proporcionalidade. Inclusive, as decisões praticadas pela Administração Pública, devem ser motivadas, visando à proteção dos direitos fundamentais, sob pena de estar incorrendo em uma antijuridicidade.

Desta feita, deve-se trabalhar com o "novo Direito Administrativo Ambiental". Nessa busca, para que haja uma proteção efetiva do meio ambiente ecologicamente equilibrado, o poder de polícia ambiental revela-se como um dos instrumentos mais eficazes de que dispõe a Administração Pública, exigindo-se sua vinculação aos mandamentos constitucionais, devendo a sua atuação ser pautada sob a forma preventiva e responsiva, imbuída de um agir 
ético por parte dos seus agentes públicos.

\section{NOTAS:}

1. Especificamente sobre o tema: FREITAS, Juarez. Discricionariedade administrativa e o direito fundamental à boa administração pública. 2. ed. São Paulo: Malheiros, 2009.

2. Ver a respeito do direito fundamental ao meio ambiente ecologicamente equilibrado, as obras de MEDEIROS, Fernanda Luiza Fontoura. Meio Ambiente: direito e dever fundamental. Porto Alegre: Livraria do Advogado Editora, 2004; SARLET, Ingo Wolfgang. A eficácia dos direitos fundamentais: uma teoria geral dos direitos fundamentais na perspectiva constitucional. 10. ed. Porto Alegre: Livraria do Advogado, 2009; TEIXEIRA, Orci Paulino Bretanha. O Direito ao ambiente equilibrado como direito fundamental. Porto Alegre: Livraria do Advogado, 2006.

3. Carta dos Direitos Fundamentais da União Europeia. Disponível em: < http://www.europarl.europa.eu/ charter/pdf/text_pt.pdf>. Acesso em: 01 ago. 2018.

4. BRASIL. Supremo Tribunal Federal. ADI 2586/DF. Relator: Min. Carlos Velloso. Disponível em: < http:// redir.stf.jus.br/paginadorpub/paginador.jsp?docTP=AC\&doclD=266853>. Acesso em: 01 ago. 2018.

5. Importante destacar que discricionariedade não se confunde com arbitrariedade. Conforme destaca Hely Lopes Meirelles, a discricionariedade é liberdade de agir dentro dos limites legais, enquanto a arbitrariedade, a ação fora ou excedente da lei, com abuso ou desvio de poder. $O$ ato discricionário, quando se atém aos critérios legais, é legítimo e válido; o ato arbitrário, no entanto, sempre ilegítimo e inválido; nulo, portanto. In: MEIRELLES, Hely Lopes. Direito administrativo brasileiro. 37. ed. São Paulo: Malheiros, 2011, p. 141.

6. In: FINK, Daniel Roberto. ALONSO JÚNIOR, Hamilton. DAWALIBI Marcelo. Aspectos jurídicos do licenciamento ambiental, 3. ed., Rio de Janeiro: Forense Universitária, 2004, p. 103.

7. A propósito, ver BENJAMIN, Antônio Hermann. Reflexões sobre a hipertrofia do direito de propriedade na tutela da reserva legal e das áreas de preservação permanente. In: Anais do $2^{\circ}$ Congresso Internacional de Direito Ambiental. São Paulo: imprensa Oficial, 1997.

8. Incumbe ao Estado e à própria coletividade a especial obrigação de defender e preservar, em benefício das presentes e das futuras gerações, esse direito de titularidade coletiva e de caráter transindividual (RTJ 164/158-161).

9. Entende-se por visão sistêmica, a partir do Direito Administrativo, que passa por uma evolução, quando traz para dentro da Administração o viés ambiental, dentro do escopo do Poder de Polícia Ambiental.

\section{REFERÊNCIAS BIBLIOGRÁFICAS}

ARAGÃO, Alexandre Santos de; MARQUES NETO, Floriano de Azevedo (Coords.). Direito administrativo e seus novos paradigmas. Belo Horizonte: Fórum, 2008.

BENJAMIN, Antônio Hermann. Reflexões sobre a hipertrofia do direito de propriedade na tutela da reserva legal e das áreas de preservação permanente. In: CONGRESSO INTERNACIONAL DE DIREITO AMBIENTAL, 2., 1997, São Paulo. Anais... São Paulo: Imprensa Oficial, 1997.

BINENBOJN, Gustavo. Uma teoria do direito administrativo. Rio de Janeiro: Renovar, 2006.

BRASIL. Supremo Tribunal Federal. ADI 2586/DF. Relator: Ministro Carlos Velloso. Disponível em: < $\underline{\text { http:// }}$ 
redir.stf.jus.br/paginadorpub/paginador.jsp?docTP=AC\&docID=266853>. Acesso em: 01 ago. 2018).

CARTA DOS DIREITOS FUNDAMENTAIS DA UNIÃO EUROPEIA. Nice, 07 dez. 2000. Disponível em: < http://www.europarl.europa.eu/charter/pdf/text pt.pdf>. Acesso em: 01 ago. 2018.

CAVALCANTI, Themistocles Brandão. Tratado de Direito Administrativo, 5. ed., Vol. III, Rio de Janeiro: Livraria Freitas Bastos S. A., 1964.

CONCEIÇÃO, Maria Collares Felipe de (Orgs.). Contribuições de direito do consumidor e do ambiente: 7 anos. Rio de Janeiro: Emerj, 2006.

DERANI, Cristiane. Direito ambiental econômico. 3. ed. São Paulo: Saraiva, 2008.

DI PIETRO, Maria Sylvia Zanella. Direito Administrativo, 20. ed., São Paulo: Atlas, 2007.

FINK, Daniel Robert; ALONSO JÚNIOR, Hamilton; DAWALIBI, Marcelo. Aspectos jurídicos do licenciamento ambiental. 3. ed. Rio de Janeiro: Forense Universitária, 2004.

FREITAS, Juarez. Discricionariedade administrativa e o direito fundamental à boa administração pública. 2. ed. São Paulo: Malheiros, 2009.

A interpretação sistemática do direito. 5. ed. São Paulo: Malheiros, 2010.

O controle dos atos administrativos e os princípios fundamentais. São Paulo: Malheiros, 2009.

JUSTEN FILHO, Marçal. Curso de direito administrativo. 10. ed. rev., atual. e ampl. São Paulo: Editora Revista dos Tribunais, 2014.

MACHADO, Paulo Affonso Leme. Direito Ambiental Brasileiro, 18. edição rev., atual. e ampl. São Paulo: Malheiros Editores, 2010.

MEDAUAR, Odete. Direito Administrativo Moderno, 11. ed., rev. e atual. São Paulo: Revista do Tribunais, 2007.

MEDEIROS, Fernanda Luiza Fontoura. Meio Ambiente: direito e dever fundamental. Porto Alegre: Livraria do Advogado Editora, 2004.

MEIRELLES. Hely Lopes. MEIRELLES, Hely Lopes. Direito administrativo brasileiro. 37. ed. São Paulo: Malheiros, 2011.

. Direito Municipal Brasileiro, 11. ed., São Paulo: Malheiros Editores, 2000.

MELLO, Celso Antonio Bandeira de. Curso de direito administrativo. 25. ed. São Paulo: Malheiros, 2008.

Curso de direito administrativo. 11. ed., São Paulo: Malheiros, 1999, p. 68.

MOREIRA NETO, Diogo de Figueiredo. Curso de Direito Administrativo, 14. ed. Rio de Janeiro: Editora Forense, 2005. 
SARLET, Ingo Wolfgang. A eficácia dos direitos fundamentais: uma teoria geral dos direitos fundamentais na perspectiva constitucional. 10. ed. Porto Alegre: Livraria do Advogado, 2009.

SCHMIDT, Cíntia. Poder de polícia ambiental e o princípio da prevenção. 2012. Dissertação (Mestrado) - Curso de Direito, Faculdade de Direito, Pontifícia Universidade Católica do Rio Grande do Sul, Porto Alegre, 2012.

Princípios de direito ambiental. Interesse Público. Belo Horizonte, ano 13, n.69 set. / out. 2011.

SILVA, Paulo Régis Rosa da. Repartição constitucional de competências em matéria ambiental. Revista do Ministério Público, Porto Alegre, Nova fase, 1 (n. 27), 1992.

SILVA, José Afonso da. Direito ambiental constitucional, 4. ed. rev. e atual. São Paulo: Malheiros, 2003.

TEIXEIRA, Orci Paulino Bretanha. O Direito ao ambiente equilibrado como direito fundamental. Porto Alegre: Livraria do Advogado, 2006. 